\title{
Sepsiste Statinlerin Rolü
}

\section{The Role of Statins in Sepsis}

\section{Cansu GÖNCÜOG̃LU'(IID), Hafsa Nur ÇETINADAM'(IID), Kutay DEMIRKAN'(IiD), Serhat ÜNAL²(ID)}

\author{
${ }^{1}$ Hacettepe Üniversitesi Eczacılık Fakültesi, Klinik Eczaclık Anabilim Dalı, Ankara, Türkiye \\ ${ }^{2}$ Hacettepe Üniversitesi Tıp Fakültesi, İnfeksiyon Hastalıkları ve Klinik Mikrobiyoloji Anabilim Dalı, Ankara, Türkiye
}

Makale atıfı: Göncüoğlu C, Çetinadam HN, Demirkan K, Ünal S. Sepsiste statinlerin rolü. FLORA 2021;26(3):369-77.

\section{ÖZ}

Sepsis, bakteri, virüs, parazit veya fungal mikroorganizmaların neden olduğu infeksiyona karşı düzensiz konak yanıtına bağlı organ disfonksiyonu olarak tanımlanmakta, morbidite veya mortaliteye neden olabilmektedir. Statinlerin ateroskleroz ve çeşitli kardiyovasküler hastalıklardaki yararı, yüksek kolesterol düzeylerini düşürerek endotelde yaptığı olumlu etkiyle açıklanmaktadır. Statinlerin lipit düşürücü etkilerine ek olarak antiinflamatuvar, antitrombotik, antioksidan etki gibi pleiotropik etkileri de bulunmaktadır. Statinlerle yapılan ön tedavinin sepsiste sağkalımı etkileyebileceği gösterilmiştir. Sepsis ve septik şokta inflamatuvar mediyatörlere maruz kalan endotel hücrelerinden sitokin salınımı, prokoagülan moleküller, trombosit üretimi teşvik edilmektedir. Ayrıca sepsiste inflamasyon gelişmesiyle nötrofil, fagosit artışı nedeniyle enfekte olan dokuda damar permeabilitesi artmakta ve doku hasarı meydana gelmektedir. Sonuçta vasküler tonusu düzenleyen homeostaz bozulmakta ve endotel hasarı meydana gelmektedir. Statinler endotelde vasküler gevşemeyi sağlayarak, adezyon molekülleri ve sitokinlerin ekspresyonunu azaltarak sepsise etki etmektedir. Güncel bilgiler ışığında, sepsis tedavisinde, pleiotropik etkilerinden yararlanmak için statin kullanımının önerilebilmesi için daha kapsamlı ve daha fazla sayıda çalışmaya ihtiyaç duyulmaktadır.

Anahtar Kelimeler: Sepsis; Septik şok; Statin; Antiinflamatuvar etki; Pleiotropik etki

\section{ABSTRACT}

\section{The Role of Statins in Sepsis}

\section{Cansu GÖNCÜOG̃LU', Hafsa Nur ÇETiNADAM', Kutay DEMIRKAN', Serhat ÜNAL²}

\footnotetext{
${ }^{1}$ Department of Clinical Pharmacy, Hacettepe University Faculty of Pharmacy, Ankara, Turkey

2 Department of Infectious Diseases and Clinical Microbiology, Hacettepe University Faculty of Medicine, Ankara, Turkey
}

\begin{abstract}
Sepsis is defined as organ dysfunction due to an irregular host response to infection caused by bacteria, viruses, parasites or fungal microorganisms and may cause morbidity or mortality. The benefit of statins in atherosclerosis and various cardiovascular diseases is explained by their positive effect on the endothelium by lowering high cholesterol levels. Statins have pleiotropic effects such as anti-inflammatory, antithrombotic and antioxidant effects in addition to their lipid lowering effects. It has been shown that pretreatment with statins may affect survival in sepsis. In sepsis and septic shock, cytokine release from endothelial cells, procoagulant molecules and thrombocyte production are encouraged. In addition, with the development of inflammation in sepsis, vascular permeability increases in the infected tissue due to the increase of neutrophils and phagocytes and tissue damage occurs. Thus, homeostasis regulating vascular
\end{abstract}

Geliș Tarihi/Received: 04/03/2021 - Kabul Ediliș Tarihi/Accepted: 30/08/2021

${ }^{\circ}$ Telif Hakkı 2021 Flora. Makale metnine www.floradergisi.org web adresinden ulașılabilir 
tone is disturbed and endothelial damage is formed. Statins act on sepsis by providing vascular relaxation in the endothelium and reducing the expression of adhesion molecules and cytokines. In the light of current knowledge, more comprehensive studies are needed to recommend the use of statins to benefit from its pleiotropic effects in the treatment of sepsis.

Key Words: Sepsis; Septic shock; Statin; Antiinflammatory effect; Pleiotropic effect

\section{GiRiș}

Sepsis, infeksiyona karșı düzensiz konak yanıtına bağlı organ disfonksiyonu olarak tanımlanmaktadir ${ }^{[1]}$. Temelinde, bakteri, virüs, parazit veya fungal mikroorganizmaların neden olduğu infeksiyon sonrası, coklu organ yetmezliğine yol açabilen, morbidite ve mortaliteye neden olabilen inflamatuvar yanıt yatmaktadır. Sepsisin görülme sıklı̆g yaș, cinsiyet ve 1rka göre değișkenlik göstermektedir. Özellikle yenidoğan ve 65 yas üstü popülasyonda yaygın görülmektedir ${ }^{[2,3]}$. Septik sok ise yüksek mortalite riski ile ilișkili dolașımsal ve hücresel/metabolik disfonksiyon gözlenen sepsis alt kümesidir. Septik sok, sepsis hastasında yeterli sıvı resisütasyonuna rağmen ortalama arteryel basıncın $\leq 65 \mathrm{mmHg}$ ve laktat düzeyinin $\geq 2 \mathrm{mmol} / \mathrm{L}$ olmasi durumudur ${ }^{[4]}$. Sepsisin global epidemiyolojik yükünü kestirmek oldukça zor olsa da, her yıl dünya capında 30 milyon insanı etkilediği ve 6 milyon insanın ölümüne neden olduğu tahmin edilmektedir ${ }^{[5]}$

Sepsis tedavisinin, tanıdan sonraki ilk 1 saat içerisinde bașlaması önerilmektedir. $\mathrm{Bu} 1$ saatlik sürecte kan kültürlerinin alınması ve laktat seviyesinin ölçülmesi, sıvı replasmanının yapılması, antibiyotik bașlanması, yașamı tehdit eden hipotansiyon varlığında vazopressör ilaç bașlanması önerilmektedir ${ }^{[6]}$. Hemodinamik stabilitenin sağlanamadığı durumlarda kortikosteroid tedavisi, kan glukozu kontrolü ve gerektiğinde insülin tedavisi önerilmektedir. Venöz tromboemboli profilaksisi için kontrendikasyon olmadığı sürece heparin kullanımı, non-steroidal antiinflamatuvar ve antikoagülan ilaç kullanımı, mekanik ventilasyon, koagülopati, ileri yas gibi gastrointestinal kanama risk faktörü bulunan hastalarda stres ülseri profilaksisi önerilmektedir ${ }^{[7]}$.

$\mathrm{Bu}$ derlemede statinlerin sahip olduğu pleiotropik etkiler aracılığ ile sepsis patogenezine etkisi incelenmiștir.

\section{Sepsis Patofizyolojisi}

Sepsis hastalarında infeksiyonun en sik nedeni gram-pozitif ve gram-negatif bakterilerdir. En yaygin görülen patojen türleri Staphylococcus aureus, Staphylococcus pneumoniae, Enterococcus, Escherichia coli ve Pseudomonas aeruginosa'dir ${ }^{[8]}$. Sepsiste inflamatuvar yanit, gram-negatif bakterilerin hücre duvarı komponenti olan endotoksin lipopolisakkaritlere (LPS), gram-pozitif bakterilerin ekzotoksinleri ve hücre duvarı yapılarına (peptidoglikan ve teikoik asit), fungal veya viral antijenlere karșı gelișmektedir ${ }^{[9]}$. Mikroorganizma dolașıma karıștığında mikrobiyal komponentler (endotoksin, ekzotoksin, antijen vb.) makrofaj yüzeyindeki Toll-benzeri reseptörler (TLR) ve lektin reseptörleri tarafından tanınmakta ve inflamatuvar kaskadın bașlamasına neden olmaktadırlar. Oldukça karmașık enflamasyon kaskadına rağmen, tümör nekroz faktör-alfa (TNF- $\alpha$ ), interlökin (IL)-1 ve IL-6 sepsiste enflamasyonu tetikleyen temel sitokinlerdir ${ }^{[10]}$.

Gram-negatif bakterilerde bulunan LPS'nin lipit A kısmı immün sistem tarafından tanınmaktadır. LPS, TLR-4 tarafından tanınmakta ve lipit bağlayan protein ile birleserek TLR-4'ü aktive etmektedir. TLR-4, proinflamatuvar sitokinleri ve transkripsiyon faktörü olan nükleer faktör kappa $\mathrm{B}$ (NF-kB)'yi aktive eder ve sinyal yolağını başlatır. NF-kB aktivasyonu IL-1, IL-2, IL-6, IL-8, TNF- $\alpha$, platelet aktive edici faktör ve interferon gama gibi birçok inflamatuvar sitokinin transkripsiyonu gerçekleștirmektedir. $\mathrm{Bu}$ sitokinler sepsis patogenezini meydana getirmekte ve inflamatuvar yanit gelismektedir ${ }^{[1,12]}$. Gram-pozitif bakteriler LPS yapıda hücre duvarı komponenti içermediğinden, bu mikroorganizmalara karșı sitokin yanıtı farklı yollardan olușmaktadır. Gram-pozitif bakterilerin hücre yapisı peptidoglikan ve teikoikasit yapidadir. Bu ekzotoksin yapilar kompleman zinciri aktive ederek lenfosit proliferasyonuyla monosit ve makrofajlardan IL-1, IL-6 ve TNF- $\alpha$ üretimini artırmakta ve inflamatuvar yanıt gelișmektedir ${ }^{[13]}$. 


\section{Sepsis ve Endotel}

Endotel yapısı vasküler tonusun düzenlenmesi, lökosit ve trombosit adezyonunun regülasyonunda önemli bir role sahiptir ${ }^{[14]}$. Endotel hücreleri, inflamatuvar mediyatörlere maruz kalınca adezyon molekülleri ve beyaz kan hücreleri artmaktadır. Aynı zamanda enflamasyonlu bölgede nötrofil, fagosit artısı ile infekte dokuda kan damarlarının geçirgenliği artmaktadır. Damar geçirgenliğinin art- ması vasküler tonda değișikliklerle mikrovasküler tromboza neden olmakta ve bunun sonucunda endotel hasarı meydana gelmektedir. Endotel hasarıyla, kanın mikrosirkülasyonda göllenmesi, dolașımdaki kan volümünü azaltmakta ve bu durum organ perfüzyon bozukluğu ve organ yetersizliğiyle sonuclanmaktadır (Sekil 1) ${ }^{[15]}$.

Endotelin-1 (ET-1), endotelden salınan, vazokonstriksiyondan sorumlu peptittir. ET-1 fizyolojik

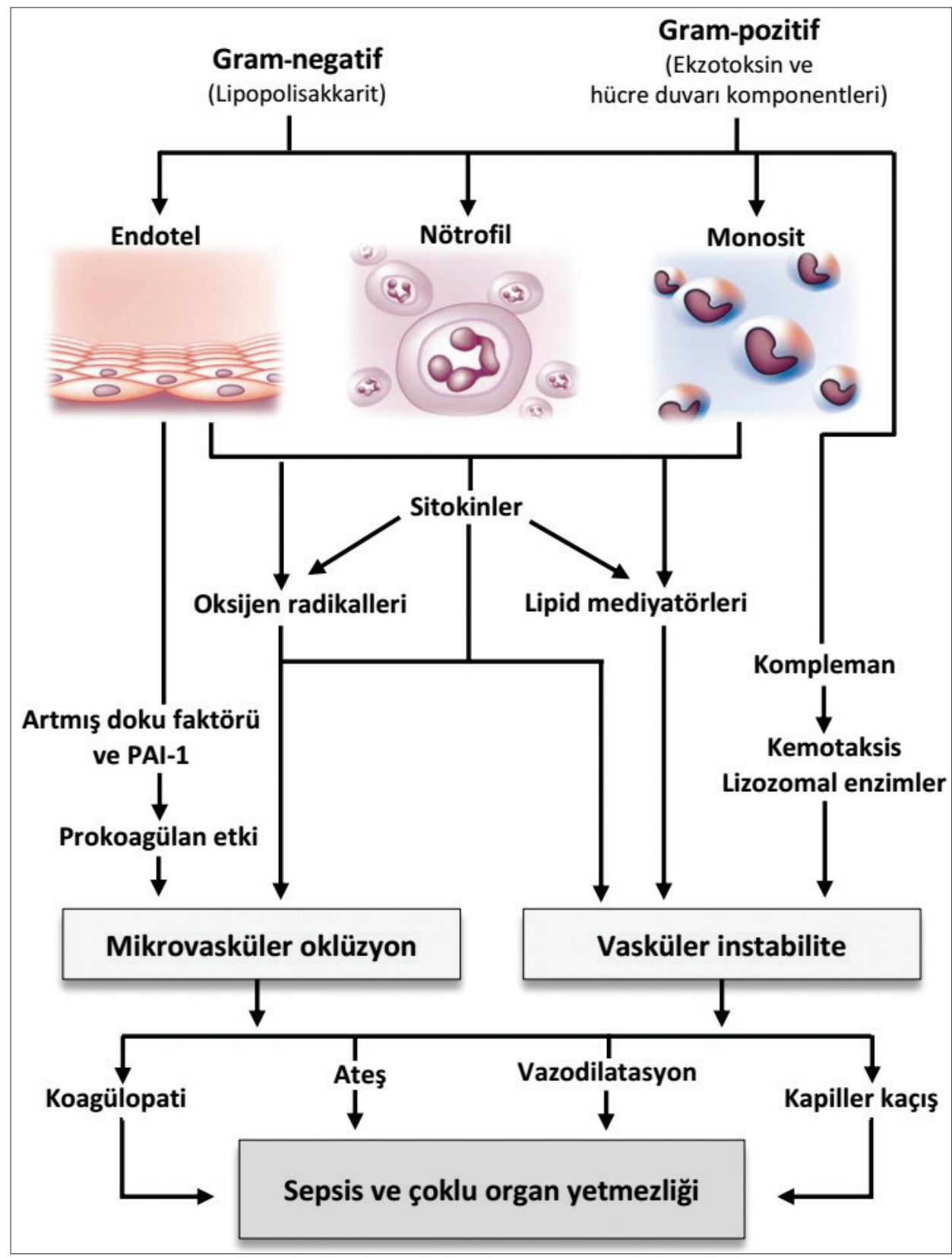

Şekil 1. Sepsiste patojenik yolaklar ${ }^{[60]}$. 
koșullarda düșük miktarda olup, sepsis gibi fizyopatolojik kosullarda endotelden ET-1'in sentezi artmaktadır ${ }^{[16]}$. ET-1, endotel hücrelerinde vazokonstriktör etkisinin yanı sıra sitokin salınmasını, reaktif oksijen türlerinin (ROT) üretimini ve salınmasını uyarmaktadır. ET-1 süperoksit üretimini artirarak oksidatif strese neden olmakta ve artan oksidatif stres endotel hasarını artırmaktadır ${ }^{[9,17]}$.

\section{Sepsis ve Nitrik Oksit}

Endotel hücrelerinden sentezlenen endotelyal nitrik oksit (NO), vasküler gevsemeyi düzenlemekte, trombosit agregasyonunu önlemekte ve vasküler duiz kas proliferasyonunu inhibe etmektedir. NO, endotelyal nitrik oksit sentaz (eNOS) ve indüklenebilir nitrik oksit sentaz (iNOS) arac1lığıyla endotelden sentezlenmektedir. eNOS aracılığıla üretilen NO, vasküler tonusu koruyarak pıhtılașma ve inflamatuvar kaskadları baskılarken; iNOS aracılığıyla üretilen NO, lökosit adezyonunuyla inflamatuvar yanıtı artırmaktadır. Sepsiste TNF- $\alpha$ 'nın uyarılmasinın ardindan TNF- $\alpha$, iNOS aracılığıyla NO üretmektedir. iNOS ekspresyonunda artıș sonucu endotel disfonksiyonu, apoptoz ve coklu organ yetmezliği görülmektedir. Sepsisin bașlangicinda iNOS ve eNOS aracilı NO üretimi artmaktadır; ancak sepsis ilerledikçe PI3-K/Akt yolağında eNOS fosforilasyonunu önleyen anormallikler olduğu düșünülmektedir. Sepsis, eNOS fonksiyonunda bir azalma ve iNOS ekspresyonunda artıs ile sonuçlanmaktadır ${ }^{[17,18]}$.

\section{Sepsis ve Koaguilasyon}

Sepsiste koagülasyon kaskad1; sitokinler, endotel hücrelerindeki doku faktörü, LPS ve diğer mikrobiyolojik ürünler tarafından aktive edilmektedir. Ayrıca IL-1, IL-6 gibi prokoagülanların etkisinin güclenmesi; antitrombin, protein $\mathrm{C}$ gibi antikoagülanların etkisinin azalması da koagülasyon artıșına katkıda bulunmaktadır. Doku faktörünün aktive edilmesi ile koagülasyon kaskadında, protrombin trombine dönüșmekte ve fibrinojenden fibrin oluşmaktadır. Fibrin olușumuyla birlikte plazminojen aktivitör inhibitörü-1 (PAI-1)'in ekspresyonu da artmaktadir. $\mathrm{Bu}$ durum plazminojenden plazmin olușmasını önleyerek fibrinolizde bozulmaya neden olmaktadır. Fibrin artıșı, küçük kan damarlarında fibrin tıkac olușturarak doku perfüzyonunu bozmakta ve organ yetersizliği gelișmektedir ${ }^{[19,20]}$.
Doğal antikoagülanlardan protein C, koagülasyon kaskadında önemli bir yere sahiptir. Trombin ve trombodulinin birleșmesi ile olușan trombin ve trombodulin kompleksi protein C'yi, aktif protein C (APC)'ye dönüștürmektedir. APC, koagülasyon kaskadında faktör Va ve faktör VIla'yı etkisiz hale getirerek koagülasyon kaskadını bloke etmektedir. Sepsis hastalarında APC ve endotel kaynaklı trombodulin düzeyleri düșuik bulunmuștur. $\mathrm{Bu}$ durum sepsiste APC takviyesi ile koagülasyonu azaltıp, fibrinolizi artırmanın tedavide etkili olabileceğini düșündürmüștür. Böylece antitrombotik ve profibrinolitik etkinliğe sahip rekombinant aktive edilmis protein C (drotrecogin alfa, rhAPC) gelistirilmis ve sepsis tedavileri arasında yerini almıștır ${ }^{[19,21]}$.

\section{Statinlerin Farmakolojisi}

Statinler, kolesterol biyosentezinde hiz kisitlay1c1 enzim olan 3-hidroksi-3-metilglutaril-koenzim-A redüktazın kompetitif inhibitörüdür ve 3 -hidroksi-3-metilglutaril-koenzim-A'nın mevalonata dönüșümünü inhibe etmektedir. Böylece total kolesterol, düsüuk dansiteli lipoprotein (LDL), apoliprotein-B ve trigliserit seviyelerini düsüurmektedir. Statinlerin ateroskleroz ve cesitli kardiyovasküler hastalıklardaki yararı, yüksek kolesterol düzeylerini düsürrerek endotelde yaptığı olumlu etkiyle açıklanmaktadır. Yapılan klinik calıșmalarda statinlerin koroner arterlerde plak boyutunu ve LDL düzeylerini azaltarak, koroner kalp hastalıkları ve inmede sağkalımı arttırdığı gösterilmiștir ${ }^{[22]}$.

Statinler elde edilișlerine göre doğal (pravastatin) ve sentetik (atorvastatin, rosuvastatin) olarak sınıflandırlırken, metabolizmalarına göre ise hidrofilik (pravastatin, rosuvastatin) ve lipofilik (simvastatin, atorvastatin) olarak siniflandırılmaktadır ${ }^{[23]}$.

Statinlerin lipit düsüürücü etkilerine ek olarak pleiotropik etkileri de bulunmaktadir ${ }^{[24]}$.

- Endotel fonksiyonuna etki

- Anjiyogenez

- Plak stabilitesi

- Trombosit agregasyonu

- Antitrombotik etki

- Antioksidan etki

- Antiinflamatuvar etki

- İmmünmodülasyon 


\section{Sepsiste Statinlerin Rolii}

Statinler kardiyovasküler hastalıklarda lipit düsürücü role sahiptir. Ancak zamanla statinlerin lipit düșürücü etkilerinden bağımsız olarak, sepsis veya infeksiyon durumlarında antiinflamatuvar, immünmodülatör gibi pleiotropik etkiler gösterdiği bulunmustur. Yapilan deneysel calıșmalar statinlerle yapılan ön tedavinin sepsiste sağkalımı iyileștirebileceğini göstermiștir. Sepsis ve septik sokta inflamatuvar mediyatörlere maruz kalan endotel hücrelerinden sitokin salınımı, prokoagülan moleküller, trombosit, platelet aktive edici faktör ve NO üretimi tesvik edilmektedir. Ayrıca enflamasyonlu bölgede nötrofil, fagosit artıșıla birlikte adezyon molekülleri ve beyaz kan hücrelerinin say1sı artmaktadır. Bunun sonucunda vasküler tonusu düzenleyen homeostaz bozulmakta ve endotel hasarı meydana gelmektedir. Endotel fonksiyonunun bozulmasıyla NO üretiminde azalma vasküler gevsemeyi engellemektedir. Sepsiste, statinler mevalonat yolağını inhibe ederek veya PI3K/Akt yolunu uyararak NO biyoyararalanımını artırır ve endotelde vasküler gevsemeyi sağlar ${ }^{[25,26]}$. Yapılan bir calıșmada atorvastatinin, NO ve endotel kaynaklı hiperpolarizan faktörün aracılık ettiği endotel bağımlı gevșeme nedeniyle olușan vasküler endotelyal disfonksiyonu iyileștirdiği gösterilmiștir ${ }^{[27]}$.

Statinler, adezyon molekülleri ve sitokinlerin ekspresyonunu azaltarak antiinflamatuvar etki oluşturmaktadır. Yapılan hayvan çalısmaları, sepsiste statinlerin faydalarını desteklemiștir. Ando ve arkadassları tarafından septik farelerde, serivastatin ön tedavisinin sağkalıma etkisini değerlendirmek amacıyla yapilan calıșmada, serivastatinin TNF- $\alpha$ ve IL-1 serum düzeylerini 2 saatte; NO, nitrit ve nitrat düzeylerini 8 saatte azalttığı ve 7 günlük mortalite oranına olumlu katkı sağladığı gösterilmiștir. Sepsis olușmadan statin kullanımının, LPS kaynaklı sitokin üretimini engellediği bildirilmiștir ${ }^{[28]}$. Bir bașka calıșmada, simvastatinin, sepsis kaynakl mortalite ve akut böbrek hasarını sistemik dolașım ve tübüler hipoksiye olumlu etki ederek iyileștirdiği gösterilmiștir ${ }^{[29]}$. Simvastatinin farklı dozlarının serum fizyolojik ile karșılaștırıldığı bir çalıșmada ise, nitrit konsantrasyonu simvastatin kullanan grupta daha duișuik bulunmuștur. Ayrıca, serum fizyolojik grubunda farelerin vazopressöre verdiği yanıt, simvastatin grubuna göre anlamlı derecede düșük bulunmustur $^{[30,31]}$. Bir bașka in vitro calıșmada ise statinlerin NF-kB'nin aktivasyonunu ve böylece sitokin üretimini azalttığ1 gösterilmiștir ${ }^{[32]}$. Zhang ve arkadașları tarafından yapilan in vitro çalıșmada, statin ön tedavisinin kardiyak fonksiyonun korunması, inflamatuvar sitokinlerin zayıflatılması, akciğerde nötrofil infiltrasyonunun zayıflatılması ve T hücresi ișlev bozukluğunu inhibe edilmesi ile sepsiste sağkalımı iyileștirdiği saptanmıștır ${ }^{[33]}$. Bu hayvan calıșmaları statinlerin sepsiste sağkalımı artırabileceğini, hemodinamik parametrelere olumlu etkisinin olabileceğini ve sepsis sendromuna neden olan sinyal kaskadını inhibe edebileceğini göstermektedir.

Sepsis gelisen insanlarda yapılan bir calıșmada NF-kB'nin aktivasyonunu ile proinflamatuvar mediyatörlerin salınımı hastalık siddeti ile ilișkili bulunmuștur $^{[34]}$. Cift kör plasebo kontrollü randomize bir çalısmada akut bakteriyel infeksiyonu olan hastalarda statin tedavisinin, sepsis insidansını ve inflamatuvar sitokin düzeylerini azaltıp azaltmadığı incelendiğinde, 72 saat simvastatin tedavisinden sonra, IL-6 ve TNF- $\alpha$ düzeylerinde anlamlı azalma görülmüștür ${ }^{[35]}$. Yapılan retrospektif calıșmada statin kullanımının, sepsis insidansını ve mortaliteyi azaltabileceği bildirilmiștir ${ }^{[36,37]}$. Diyabetik hastalarda yapilan retrospektif calıșmada statin tedavisine bașladıktan sonra pnömoni geliștirme oranları incelenmiș ve statin kullanımı pnömoni gelișme riskini önemli ölçüde düșürdüğü saptanmıștır. Diyabetik hastalarda statinlerin infeksiyona kars1 koruyucu etkisinin olabileceği bildirilmektedir [38]

Prospektif gözlemsel bir çalıșmada, statin kullanımının, infeksiyon ilișkili mortalite riskini azalttığı gösterilmiștir ${ }^{[39]}$. Prospektif bir kohort calıșmasında hastaneye yatıșından önce statin kullanan ve kullanmayan hastalar karșılaștırıldığında, statin kullanmayan grupta siddetli sepsis gelișme oranı \%19 iken, statin kullanan grupta bu oran \%2.4 olarak saptanmıștır. Statinlerin siddetli sepsis gelișme rölatif riskini azalttığı bildirilmiștir. Statin almayan grupta yoğun bakım ünitesine yatıs oranları statin alan gruba göre anlaml derecede yüksek bulunmustur ${ }^{[40]}$. Ayrıca enflamasyonda TLR-4 tarafindan uyarılan proinflamatuvar sitokin salınmasının, çift kör plasebo kontrollü bir çalıșmada simvastatin ve LPS uygulamasıyla, LPS'ye yanıt olarak TLR2 ve TLR-4 ekspresyonunu azalttığı gösterilmiștir. 
$\mathrm{Bu}$ çalıșmaların sonucunda statin kullanımıla sepsis siddeti ve mortalite riskinde azalma olabileceği düșünülmüștür ${ }^{[41]}$. Belirtilen antibakteriyel etkilerin statinlerin lipit düșürücü etkisinden bağımsız olduğu düsüunülmektedir ${ }^{[42]}$. Simvastatinin, rosuvastatine göre daha iyi antibakteriyal etki göstermesine, simvastatin ve atorvastatinin 30 günlük mortalite bakımından rosuvastatine üstün olmasına rağmen, rosuvastatinin lipit düșürme kapasitesinin daha iyi olduğunu gösteren çalıșma bu durumu kanıtlar niteliktedir $^{[43]}$. Bu nedenle statinlerin koruyucu etkisinin ilaca veya sınıfa göre değișkenlik gösterebileceği düșünülmektedir.

Sepsiste enflamasyon gelișmesiyle nötrofil, fagosit artıșı olmakta, lökositlerin vasküler endotelyum üzerine yapıșması ve göcü artmaktadır. Infekte olan dokuda damar permeabilitesi artmakta ve doku hasarı meydana gelmektedir ${ }^{[44]}$. Statinler, lökosit endotel etkileșimini engelleyerek nötrofil ve lökositlerin iltihaplı bölgeye sızmasını önleyerek doku hasarı azaltılmaktadır ${ }^{[45]}$. Sepsis patogenezinde endotelden salınan vazokonstriktör etkili ET-1 düzeyleri artması ile ROT ve süperoksit radikal üretimi uyarılarak oksidatif stres meydana gelmektedir ${ }^{[9]}$. Bunun sonucunda anormal damar gerimi ve endotel ișlev bozukluğu olușmaktadır. Statinler, ET-1'in salınımını inhibe ederek endotel fonksiyonunda vazodilatasyona yol acmaktadır. Ayrıca statinler, süperoksit radikalleri ve ROT olusumunu inhibe ederek de endotelde vazodilatasyona neden olmaktadır ${ }^{[46]}$. Sepsiste sitokinlerin koagülasyon kaskadını aktive etmesiyle doku faktörü ve PAI-1'in ekspresyonu artar. Bu durum fibrin artıșı ve fibrin tıkac olușumuyla perfüzyonu bozmaktadır ${ }^{[19,20]}$. Statinler, trombosit agregasyonunu uyaran TXA2 sentezini inhibe ederek antitrombotik etki göstermektedir ${ }^{[47] .}$

Statinlerin sepsiste yararlı olabileceğini gösteren klinik calıșmalar bulunmaktadır. Sepsiste statin kullanımının organ disfonksiyonu ve mortalite üzerine koruyucu etkisi olduğu düșünülmektedir. Yapılan klinik bir çalıșmada bakteriyel infeksiyon nedeniyle hastaneye yatırılan, Çin kökenli yașlı ( $\geq 65$ yas) hastalarda statinlerin sepsis ve infeksiyona bağlı gelișen organ fonksiyon bozukluğu ve mortalite üzerine koruyucu etkisi incelenmiștir. Retroprospektif kohort calıșmasında, hastaneye yatıștan önce en az 1 aydır statin kullanan ve statin kullanmayan veya 1 aydan kısa süredir statin kullanan hastalar değerlendirilmiștir. Hastanaye yatıștan 1 ay öncesinde statin tedavisi alan hastalarda sepsis ve infeksiyona bağlı organ disfonksiyonunda önemli azalma görülmüștür ${ }^{[48]}$. Thomsen ve arkadașları tarafından yapılan klinik araștırmanın sonuçlarına göre sepsis ile ilișkili mortalitenin azaltılması için uzun süreli statin kullanımı gerekmektedir. Bu çalıșmada, sepsiste 180 güne kadar statin tedavisi kullanilması sonucu mortalitede anlamlı azalmalar gösterilmiștir ${ }^{[49]}$. Novack ve arkadașları tarafından yapılan calıșmada, statinlerin organ disfonksiyonunu önleyerek sepsis siddetini azalttığı gösterilmiștir ${ }^{[35]}$. Atorvastatin ile yapilan calıșmada ise önceden statin kullanan sepsis hastalarının IL-6 seviyeleri, statin kullanmayan hastalara göre düsük bulunmus ve statin kullanımı sağkalımı olumlu etkilemiștir ${ }^{[50]}$. Koroner arter hastalığı, sitomegalovirüs pozitifliği ve yüksek C-reaktif protein (CRP) düzeyleri olan hastalarda statin kullanımıyla mortalitenin azaldığı gösterilmiștir $^{[51]}$. Randomize kontrollui bir calıșmada, atorvastatin ile tedavi edilen akut koroner sendromlu hastaların, plasebo grubuna kıyasla CRP'de hızlı bir düșüs yașadı̆̆ı gösterilmiștir ${ }^{[52]}$.

Literatürde statinlerin sepsiste yararl etkisinin olmadığını savunan çalıșmalar da bulunmaktadır. Yapılan bir çalıșmada, statin kullanımı ile sağkalım arasında anlamlı bir ilișki olmadığı gösterilmiștir ${ }^{[53]}$. Ayrıca statin kullanan hastaların daha fazla komorbiditeye sahip olduklarını ve statin kullanımının sepsiste klinik çıtıları etkilemediği bildirilmiștir $^{[54]}$. Sistematik bir derlemede statinlerin sepsis insidansını veya sepsis iliskili mortalite oranını azaltmadığı bildirilmiștir ${ }^{[55]}$. Bir bașka calıșmada ise statinlerin sepsis gelișimini ve infeksiyon ilișkili organ disfonksiyonunu azalttığı ancak 30 günlük mortalite, yoğun bakım ünitesi ihtiyacı ve hastanede yatıșı etkilemediği bildirilmiștir ${ }^{[48]}$. Ağır yoğun bakım hastalarında yapılan bir calıșmada ise, statin tedavisi alan sepsisli hastalarda mortalitede istatistiksel olarak anlamlı bir artış olduğu gösterilmiștir. Ancak calıșmaya alınan hastaların durumlarının ağır olmasının sonuçlara etkisinin olabileceği bildirilmiștir ${ }^{[56]}$. Randomize kontrollü calıșmaların derlendiği iki meta analize göre, kritik yoğun bakım hastalarında sadece gerekli görülmesi halinde statin kullanılması önerilmekte, sepsis yönetimine katkı sağlaması açısından kullanımı 
önerilmemektedir ${ }^{[57,58]}$. Statinlerin pleiotropik etkileri göz önünde bulundurulduğunda sepsis tedavisinde yardımcı tedavi olabileceği düșünülmüștür. Ancak statin tedavisinin, sepsiste yardimc1 tedavi olarak kullanımıla sepsis tedavisi ve önlenmesinde rolünü kesin olarak belirlemek için daha fazla randomize kontrollui çalısmalara ihtiyaç duyulmaktadir ${ }^{[59]}$.

\section{Sonuç ve Öneriler}

Statinler endotel fonksiyonlarını iyileștirip, fibrinotilik aktiviteyi arttırırken; inflamatuvar sitokin salınımı ve oksidatif stresi azaltmaktadır. Kolesterol düșürücü etkilerinden bağımsız olarak pleiotropik etkileri ile endotelyal NO üretimini arttırarak vasküler gevsemeyi sağlamakta ve ET-1 düzeylerini azaltarak vazokonstriksiyon ve oksidatif stresi önlemektedir. Sepsiste statinlerin endotelde meydana getirdiği olumlu etkiler klinik çalıșmalarla desteklenmiștir. Ayrıca sepsis ile ilișkili mortalitenin azaltılabilmesi için statin kullanımının uzun süreli olması gerektiği bildirilmiștir. Sepsis tedavisinde, pleiotropik etkilerinden yararlanmak için statin kullanımının önerilebilmesi için daha fazla çalıșmaya ihtiyaç duyulmaktadır.

\section{ÇIKAR ÇATIȘMASI}

Yazarlar bu makale ile ilgili herhangi bir çkar catıșması bildirmemișlerdir.

\section{KAYNAKLAR}

1. Barrier KM. Summary of the 2016 international surviving sepsis campaign: A clinician's guide. Critical care nursing clinics of North America 2018;30(3):311-21.

2. Martin GS, Mannino DM, Eaton S, Moss M. The epidemiology of sepsis in the United States from 1979 through 2000. The New England J Med 2003;348(16):1546-54.

3. TATD Kritik Bakım Çalışma Grubu. Sepsis tanı ve tedavi kılavuzu 2018 [Available from: https://www.tatd.org.tr/uploads/tbl_calisma_grubu_belgeleri/5bdc0b59545b8_tbl_calisma_grubu_belgeleri2018113121.pdf.

4. Singer $M$, Deutschman CS, Seymour CW, Shankar-Hari M, Annane D, Bauer $M$, et al. The Third International Consensus Definitions for Sepsis and Septic Shock (Sepsis-3). Jama 2016;315(8):801-10.

5. Fleischmann C, Scherag A, Adhikari NK, Hartog CS, Tsaganos $T$, Schlattmann $P$, et al. Assessment of global incidence and mortality of hospital-treated sepsis. . Am I Respir Crit Care Med 2016;193(3):259-72.

6. Levy MM, Evans $L E$, Rhodes A. The surviving sepsis campaign bundle: 2018 update. Crit Care Med 2018;46(6):9971000.
7. Rhodes A, Evans LE, Alhazzani W, Levy MM, Antonelli M, Ferrer $R$, et al. Surviving sepsis campaign: International guidelines for management of sepsis and septic shock. Crit Care Med 2017;45(3):486-552.

8. Vincent JL, Sakr Y, Sprung CL, Ranieri VM, Reinhart K, Gerlach $\mathrm{H}$, et al. Sepsis in European intensive care units: results of the SOAP study. Crit Care Med 2006;34(2):344-53.

9. Bone RC. The pathogenesis of sepsis. Ann Intern Med 1991;115(6):457-69.

10. Fry DE. Sepsis, systemic inflammatory response, and multiple organ dysfunction: the mystery continues. Am Surg 2012; 78(1):1-8.

11. Megyeri K, Au WC, Rosztoczy I, Raj NB, Miller RL, Tomai $M A$, et al. Stimulation of interferon and cytokine gene expression by imiquimod and stimulation by Sendai virus utilize similar signal transduction pathways. Mol Cell Biol 1995; 15(4):2207-18.

12. Raetz $C R$, Whitfield C. Lipopolysaccharide endotoxins. Annu Rev Biochem. 2002; 71:635-700.

13. Baddeley $A D$ SJ. Sepsis syndrome. In: Wilson WR, Sande, M.A., editor. Current Diagnosis and Treatment In Infectious Diseases. McGraw-Hill, New York2001.

14. Belloni PN, Nicolson GL. Differential expression of cell surface glycoproteins on various organ-derived microvascular endothelia and endothelial cell cultures. I Cell Physiol 1988;136(3):398-410.

15. Heffner JE, Sahn SA, Repine JE. The role of platelets in the adult respiratory distress syndrome. Culprits or bystanders? Am Rev Respir Dis 1987;135(2):482-92.

16. Miyauchi $T$, Tomobe $Y$, Shiba R, Ishikawa T, Yanagisawa M, Kimura $S$, et al. Involvement of endothelin in the regulation of human vascular tonus. Potent vasoconstrictor effect and existence in endothelial cells. Circulation 1990;81(6):1874-80.

17. Gopalakrishna D, Pennington S, Karaa A, Clemens MG. ET-1 Stimulates Superoxide Production by eNOS Following Exposure of Vascular Endothelial Cells to Endotoxin. Shock (Augusta, Ga) 2016;46(1):60-6.

18. Matsuda N, Hayashi Y, Takahashi Y, Hattori Y. Phosphorylation of endothelial nitric-oxide synthase is diminished in mesenteric arteries from septic rabbits depending on the altered phosphatidylinositol 3-kinase/Akt pathway: reversal effect of fluvastatin therapy. I Pharmacol Exp Therapeutics 2006;319(3):1348-54.

19. Liaw PC, Esmon CT, Kahnamoui K, Schmidt S, Kahnamoui $S$, Ferrell $G$, et al. Patients with severe sepsis vary markedly in their ability to generate activated protein C. Blood 2004;104(13):3958-64.

20. Cavaillon MM, Adib-Conquy M, Fitting C, Adrie C, Payen D. Cytokine cascade in sepsis. Scand I Infect Dis 2003;35(9):535-44.

21. Fulcher $C A$, Gardiner JE, Griffin JH, Zimmerman TS. Proteolytic inactivation of human factor VIII procoagulant protein by activated human protein $C$ and its analogy with factor V. Blood 1984;63(2):486-9. 
22. Shepherd I, Cobbe SM, Ford I, Isles CG, Lorimer AR, MacFarlane PW, et al. Prevention of coronary heart disease with pravastatin in men with hypercholesterolemia. West of Scotland Coronary Prevention Study Group. The New England journal of medicine. 1995;333(20):1301-7.

23. Türkiye Endokrinoloji ve Metabolizma Derneği Obezite LM, Hipertansiyon Çalışma Grubu,. Dislipidemi tanı ve tedavi kılavuzu: Türkiye Endokrinoloji ve Metabolizma Derneği; 2019. Available from:https://temd.org.tr/admin/ uploads/tbl_kilavuz/20190506163838-2019tbl_kilavuz61855bdd04.pdf.

24. Shahbaz SK, Sadeghi M, Penson PE, Sahebkar AJPR. Regulatory $T$ cells: possible mediators for the anti-inflammatory action of statins. 2019:104469.

25. Peters K, Unger RE, Brunner J, Kirkpatrick CJ. Molecular basis of endothelial dysfunction in sepsis. Cardiovascular Res 2003;60(1):49-57.

26. Parker JL, Adams HR. Selective inhibition of endothelium-dependent vasodilator capacity by Escherichia coli endotoxemia. Circ Res. 1993;72(3):539-51.

27. Subramani J, Kathirvel K, Leo MD, Kuntamallappanavar G, Uttam Singh T, Mishra SK. Atorvastatin restores the impaired vascular endothelium-dependent relaxations mediated by nitric oxide and endothelium-derived hyperpolarizing factors but not hypotension in sepsis. I Cardiovascular Pharmacol 2009;54(6):526-34.

28. Ando H, Takamura T, Ota T, Nagai Y, Kobayashi K. Cerivastatin improves survival of mice with lipopolysaccharide-induced sepsis. Journal Pharmacol Exp Therapeutics 2000;294(3):1043-6.

29. Yasuda H, Yuen PS, Hu X, Zhou H, Star RA. Simvastatin improves sepsis-induced mortality and acute kidney injury via renal vascular effects. Kidney Int 2006;69(9):1535-42.

30. Giusti-Paiva A, Martinez MR, Felix JV, da Rocha MJ, Carnio $E C$, Elias $L L$, et al. Simvastatin decreases nitric oxide overproduction and reverts the impaired vascular responsiveness induced by endotoxic shock in rats. Shock (Augusta, Ga) 2004;21(3):271-5.

31. Janda $S$, Young $A$, FitzGerald $M M$, Etminan $M$, Swiston JJJocc. The effect of statins on mortality from severe infections and sepsis: a systematic review and meta-analysis. 2010;25(4):656. e7-. e22.

32. Fraunberger P, Grone E, Grone HJ, Walli AK. Simvastatin reduces endotoxin-induced nuclear factor kappaB activation and mortality in guinea pigs despite lowering circulating low-density lipoprotein cholesterol. Shock (Augusta, Ga) 2009;32(2):159-63.

33. Zhang S, Luo L, Wang Y, Rahman M, Lepsenyi M, Syk I, et al. Simvastatin protects against $T$ cell immune dysfunction in abdominal sepsis. Shock (Augusta, Ga). 2012;38(5):52431.

34. Bohrer H, Qiu F, Zimmermann T, Zhang Y, Jllmer T, Mannel $D$, et al. Role of NFkappaB in the mortality of sepsis. I Clin Invest 1997;100(5):972-85.
35. Novack V, Eisinger $M$, Frenkel $A$, Terblanche $M$, Adhikari NK, Douvdevani A, et al. The effects of statin therapy on inflammatory cytokines in patients with bacterial infections: a randomized double-blind placebo controlled clinical trial. Intens Care Med 2009;35(7):1255-60.

36. Schmidt $H$, Hennen $R$, Keller A, Russ M, Muller-Werdan $U$, Werdan $K$, et al. Association of statin therapy and increased survival in patients with multiple organ dysfunction syndrome. Intens Care Med 2006;32(8):1248-51.

37. Kruger P, Fitzsimmons $K$, Cook $D$, Jones $M$, Nimmo G. Statin therapy is associated with fewer deaths in patients with bacteraemia. Intens Care Med 2006;32(1):75-9.

38. van de Garde EM, Hak E, Souverein PC, Hoes AW, van den Bosch JM, Leufkens HG. Statin treatment and reduced risk of pneumonia in patients with diabetes. Thorax 2006;61(11):957-61.

39. Almog Y, Novack V, Eisinger M, Porath A, Novack L, Gilutz $H$. The effect of statin therapy on infection-related mortality in patients with atherosclerotic diseases. Crit Care Med 2007;35(2):372-8.

40. Almog Y, Shefer A, Novack V, Maimon N, Barski L, Eizinger $M$, et al. Prior statin therapy is associated with a decreased rate of severe sepsis. Circulation 2004;110(7):880-5.

41. Niessner A, Steiner S, Speidl WS, Pleiner J, Seidinger $D$, Maurer $G$, et al. Simvastatin suppresses endotoxin-induced upregulation of toll-like receptors 4 and 2 in vivo. Atherosclerosis 2006;189(2):408-13.

42. Lee CC, Lee MG, Hsu TC, Porta L, Chang SS, Yo CH, et al. A population-based cohort study on the drug-specific effect of statins on sepsis outcome. Chest 2018;153(4):805-15.

43. Kamat SA, Gandhi SK, Davidson M. Comparative effectiveness of rosuvastatin versus other statin therapies in patients at increased risk of failure to achieve low-density lipoprotein goals. Curr Med Res Opinion 2007;23(5):1121-30.

44. Thickett DR, Armstrong L, Christie SJ, Millar AB. Vascular endothelial growth factor may contribute to increased vascular permeability in acute respiratory distress syndrome. Am J Respir Crit Care Med 2001;164(9):1601-5.

45. Kimura M, Kurose I, Russell I, Granger DN. Effects of fluvastatin on leukocyte-endothelial cell adhesion in hypercholesterolemic rats. Arterioscler Thromb Vasc Biol 1997;17(8):1521-6.

46. Laufs U, La Fata V, Plutzky J, Liao JK. Upregulation of endothelial nitric oxide synthase by HMG COA reductase inhibitors. Circulation 1998;97(12):1129-35.

47. Vaughan Cl, Gotto AM Jr., Basson CT. The evolving role of statins in the management of atherosclerosis. I Am Coll Cardiol 2000;35(1):1-10.

48. Gui Q, Yang Y, Zhang J. Effects of statins on the development of sepsis and organ dysfunction in hospitalized older patients in China. The Brazilian journal of infectious diseases: an official publication of the Brazilian Soc Infect Dis 2017;21(3):255-62. 
49. Thomsen RW, Hundborg HH, Johnsen SP, Pedersen L, Sorensen $H T$, Schonheyder $H C$, et al. Statin use and mortality within 180 days after bacteremia: a population-based cohort study. Crit Care Med 2006;34(4):1080-6.

50. Patel JM, Snaith C, Thickett DR, Linhartova L, Melody $T$, Hawkey $P$, et al. Randomized double-blind placebo-controlled trial of $40 \mathrm{mg} /$ day of atorvastatin in reducing the severity of sepsis in ward patients (ASEPSIS Trial). Crit Care 2012;16(6):R231.

51. Horne BD, Muhlestein JB, Carlquist JF, Bair TL, Madsen TE, Hart NI, et al. Statin therapy interacts with cytomegalovirus seropositivity and high C-reactive protein in reducing mortality among patients with angiographically significant coronary disease. Circulation 2003;107(2):258-63.

52. Macin SM, Perna ER, Farias EF, Franciosi V, Cialzeta JR, Brizuela $M$, et al. Atorvastatin has an important acute anti-inflammatory effect in patients with acute coronary syndrome: results of a randomized, double-blind, placebo-controlled study. Am Heart J 2005; 149(3):451-7.

53. Leung S, Pokharel R, Gong MN. Statins and outcomes in patients with bloodstream infection: a propensity-matched analysis. Critic Care Med 2012;40(4):1064-71.

54. Goodin J, Manrique C, Dulohery M, Sampson J, Saettele $M$, Dabbagh O. Effect of statins on the clinical outcomes of patients with sepsis. Anaesth Intensive Care 2011;39(6):1051-5.

55. Deshpande A, Pasupuleti V, Rothberg MB. Statin therapy and mortality from sepsis: a meta-analysis of randomized trials. Am J Med 2015;128(4):410-7.e1.
56. Fernandez R, De Pedro VJ, Artigas A. Statin therapy prior to ICU admission: protection against infection or a severity marker? Inten Care Med 2006;32(1):160-4.

57. Thomas G, Hraiech S, Loundou A, Truwit J, Kruger P, McAuley $D F$, et al. Statin therapy in critically-ill patients with severe sepsis: a review and meta-analysis of randomized clinical trials. Minerva Anestesiol 2015;81(8):921-30.

58. Pertzov B, Eliakim-Raz N, Atamna H, Trestioreanu AZ, Yahav $D$, Leibovici L. Hydroxymethylglutaryl-CoA reductase inhibitors (statins) for the treatment of sepsis in adults - A systematic review and meta-analysis. Clin Microbiol Infect 2019;25(3):280-9.

59. Dobesh PP, Klepser DG, McGuire TR, Morgan CW, Olsen $K M$. Reduction in mortality associated with statin therapy in patients with severe sepsis. Pharmacotherapy 2009;29(6):621-30.

60. Cohen J. The immunopathogenesis of sepsis. Nature 2002;420(6917):885-91.

\section{Yazıșma Adresi/Address for Correspondence}

\section{Dr. Cansu GÖNCU்OĞLU}

Hacettepe Üniversitesi Eczacılık Fakültesi,

Klinik Eczacılık Anabilim Dalı,

Ankara-Türkiye

E-posta: cansugoncuoglu@gmail.com 